\title{
Expression of the Insulin-Like Growth Factor-II/ Mannose-6-Phosphate Receptor in Multiple Human Tissues during Fetal Life and Early Infancy*
}

\author{
BARBARA FUNK, ULRIKE KESSLER, WOLFGANG EISENMENGER, \\ ANGELA HANSMANN, HELMUT J. KOLB, AND WIELAND KIESS \\ Department of Pediatric Endocrinology, Laboratory of Cell Biology, Childrens Hospital (B.F., U.K., W.K.), \\ Institute of Forensic Medicine (W.E.), Institute of Pathology (A.H.), University of Munich, and Institute of \\ Clinical Chemistry, City-Hospital Harlaching (H.K.), Munich, Germany
}

\begin{abstract}
The insulin like growth factor-II/mannose-6-phosphate (IGF-II/ $\mathrm{M} 6 \mathrm{P})$ receptor has been detected in many cells and tissues. In the rat, there is a dramatic developmental regulation of IGF-II/M6P receptor expression, the receptor being high in fetal and neonatal tissues and declining thereafter. We have systematically studied the expression of the human IGF-II/M6P receptor protein in tissues from 10 human fetuses and infants (age 23 weeks gestation to 24 months postnatal). We have asked 1) whether there is differential expression among different organs, and 2) whether or not the human IGF-II/M6P receptor is developmentally regulated from 23 weeks gestation to 24 months postnatal. Protein was extracted from human tissues using a buffer containing $2 \%$ sodium dodecyl sulfate and $2 \%$ Triton X-100. Aliquots of the protein extracts were analyzed by sodium dodecyl sulfate-polyacrylamide gel electrophoresis and immunoblotting using an anti-IGF. II/M6P receptor antiserum (no. 66416) and ${ }^{125}$ I-protein $A$ or an immunoperoxidase stain. IGF-II/M6P receptor immunoreactivity was detected in all tissues studied with the highest amount of receptor being expressed in heart, thymus, and kidney and the lowest receptor content being measured in brain and muscle. The receptor content in ovary, testis, lung, and spleen was intermediate. The apparent molecular weight of the IGF-II/M6P receptor (220,000 kilos without reduction of disulfide bonds) varied among the different tissues: in brain the
\end{abstract}

receptor was of lower molecular weight than in other organs. Immunoquantitation experiments employing ${ }^{125}$ I-protein $A$ and protein extracts from human kidney at different ages revealed a small, albeit not significant, difference of the receptor content between fetal and postnatal tissues: as in other species, larger amounts of receptor seemed to be present in fetal than in postnatal organs. In addition, no significant difference of the receptor content between human fetal liver and early postnatal liver was measured employing ${ }^{125}$ I-protein A-immunoquantitation in three fetal and five postnatal liver tissue samples. The distribution of IGF-binding protein (IGEBP) species, another abundant and major class of IGF binding principles, was also measured in human fetal and early postnatal lung, liver, kidney, muscle, and brain using Western ligand blotting with ${ }^{125}$ I-IGF-II: as with IGF-II/M6P receptor immunoreactivity there was differential expression of the different classes of IGFBPs in the various organs. In conclusion, 1) the IGF-II/M6P receptor is present in multiple human tissues, 2) the human IGF-II/M6P receptor is variably expressed in different organs, 3 ) there is a much lesser degree of developmental regulation of IGF-II/ $\mathrm{M} 6 \mathrm{P}$ receptor expression in the human than has been reported for the rat or sheep, 4) the differential pattern of distribution of IGF-II/M6P receptor and IGFBPs in the various organs throughout fetal and early postnatal human life points to an important and tissue specific role of the IGF binding principles in development and growth. (J Clin Endocrinol Metab 75: 424-431, 1992)
$\mathrm{T}^{\mathrm{H}}$ HE insulin-like growth factor-II (IGF-II) is a polypeptide which belongs to the insulin family of polypeptide hormones that also includes IGF-I and relaxin (1-3). Although the aminoacid sequence and molecular structure of IGF-II have long been characterized $(4,5)$, its biological action and physiological role in vivo are still elusive: 1 ) it has been suggested that IGF-II plays a role in the growth and development of the central nervous system and of certain tumors (6-9). 2) Alternatively, IGF-II might be involved in fetal growth and development, since both serum IGF-II levels and tissue IGF-II messenger RNA content are high prenatally and decline after birth. Although this is true in mice, rats, and

Received August 6, 1991.

Address all correspondence and requests for reprints to: Dr. Wieland Kiess, Department of Pediatric Endocrinology, Laboratory of Cell Biology, Children's Hospital, Lindwurmstrasse 4, D 8000 Munich 2, Germany.

* This work was supported by Deutsche Forschungsgemeinschaft, Grant Ki 365/1.1, and a Nordisk Grant for the Study of Growth (to W. K.). Presented in part at the UCLA Conference on Receptors and Signal Transduction, Keystone, CO, 1990, Abstract no. F 611. sheep (10-14), in the human, IGF-II levels are lower during prenatal life and do not change dramatically after birth (1518). 3) Recently, IGF-II has been implicated in modulating the cellular uptake of lysosomal enzymes via the IGF-II/ mannose-6-phosphate (M6P) receptor (19-22). It is hypothesized that a growth factor, IGF-II, might thus be a regulator of the major degradative pathway of the cell. IGF-II binds to two high affinity receptors which are present in many cells and tissues. The IGF-I receptor prefers IGF-I over IGF-II and also binds insulin. This receptor resembles the insulin receptor and contains tyrosine kinase activity $(1,2,23,24)$. It is thought that the IGF-I receptor mediates the metabolic and growth promoting action of the IGFs (25-27). The IGF-II receptor binds IGF-II with high affinity, recognizes IGF-I only weakly, and does not bind insulin at all. This receptor does not have intrinsic tyrosine kinase activity $(24,28)$. Interestingly, the IGF-II receptor has been shown by complementary DNA cloning to be identical to the cation-independent M6P receptor (29-31). These observations were confirmed by biochemical and immunological studies (3236). The M6P receptor functions to target lysosomal enzymes 
bearing the M6P recognition marker to lysosomes (37-39). In addition, a signaling role for the IGF-II/M6P receptor has been suggested by some authors (40-45). A truncated form of the IGF-II/M6P receptor lacking the cytoplasmic domain of the membrane receptor molecule has been identified in the circulation in many species (46-48). It has been hypothesized that the process of proteolytic cleavage that leads to the production of the serum form of the IGF-II/M6P receptor serves as a major degradative pathway for the receptor (49). Recently, the levels of IGF-II/M6P receptor protein in rat, sheep, and monkey serum and tissue have been measured $(46,47,50,51)$. In this study, we measured by immunoblotting the IGF-II/M6P receptor protein content in solubilized whole tissue extracts from human fetuses and infants ranging in age from 23 weeks before to 24 months after birth. Immunoblots were analyzed to determine if there is differential expression of the IGF-II/M6P receptor among different human tissues and whether or not there exists a developmental regulation of receptor protein expression in the human. Ligand blotting employing ${ }^{125}$ I-IGF-II as the radioligand was used to compare the organ distribution of IGF-binding protein (IGFBP) species with that of the IGF-II/M6P receptor.

\section{Subjects and Methods}

\section{Tissue collection}

Tissues (kidney, brain, liver, lung, testis, ovary, spleen, thymus, muscle, heart) were collected from 10 aborted or stillborn fetuses and infants who had died suddenly (sudden infant death syndrome) or by accident. The time interval between death and removal of tissues at the Institutes of Forensic Medicine and Pathology, University of Munich, Munich, Germany, was between 4 and approximately $24 \mathrm{~h}$. Tissues were removed aseptically, diced, and immediately frozen in liquid nitrogen. The study protocol had been approved by the Ethical Committee of the Children's Hospital (University of Munich, Munich, Germany).

\section{Tissue extraction}

Approximately $20 \mathrm{mg}$ thawed tissue were placed in $1.5 \mathrm{~mL}$ plastic tubes and weighed; $0.4 \mathrm{~mL} 20 \mathrm{mmol}$ Tris, $2 \%$ Triton X-100, pH 7.4, and $0.1 \mathrm{~mL}$ Laemmli buffer containing $2 \%$ sodium dodecyl sulfate (SDS) (49) was added, and the tissues homogenized for $3 \mathrm{~min}$ with a Polytron homogenizer (Polytron PT 10-35, Bachofer, Reutlingen, Germany). The samples were boiled for $5 \mathrm{~min}$ and then incubated overnight at $4 \mathrm{C}$. The protein homogenates were then boiled again for $1 \mathrm{~min}$ and centrifuged for $5 \mathrm{~min}$ at $10,000 \times \mathrm{g}$ in a Mikrorapid/K centrifuge (Hettich, Tuttlingen, Germany). No visible pellet was seen after extraction. Aliquots of the supernatants were stored at $-20 \mathrm{C}$ until further analysis. The protein content of the tissue extracts was determined using the BCA protein assay (Pierce Chemical Co., Rockford, IL, Cat. no. 23225). Dilutions of BSA were used as protein standards.

\section{Immunoblotting}

Aliquots of the tissue extracts amounting to $0.2 \mathrm{mg}$ protein per organ examined were subjected to SDS-polyacrylamide gel electrophoresis (PAGE) under nonreducing conditions using the discontinuous buffer system of Laemmli (52). Prestained molecular weight markers were used as follows: lysozyme, 14,300; $\beta$-lactoglobulin, 18,400; carbonic anhydrase, 29,000; ovalbumin, 43,000; BSA, 68,000; phosphorylase B, 97,400; myosin, 200,000 (BRL, Eggenstein, Germany, prestained protein molecular weight standards, Cat. no. 6041LA). The electrophoresed samples were transferred onto nitrocellulose (Schleicher \& Schuell,
Dassel, Germany, Cat. no. 401180 ) by electroelution (500 mA; $80 \mathrm{~V})$, and stained using $0.1 \%$ Fast Green (Merck, Darmstadt, Germany, Cat. no. 4022 ) in $1 \%$ acetic acid. After destaining in 0.01 molar $\mathrm{NaOH}$, immunoblotting was performed using a specific antiserum against the human IGF-II/M6P receptor (no. 66416, a kind gift from Dr. W. Sly, St. Louis, MO) following an earlier described protocol (50). The antiserum was used at a final dilution of 1:2000. An immunoperoxidase staining kit (Vectastain $A B C$ kit, Vector Laboratories, Inc., Burlingame, $C A$ ) was used to detect specific protein bands on the nitrocellulose filters employing horse radish peroxidase and an avidin-biotin enhancing step. After drying overnight, the nitrocellulose sheets were photographed.

\section{Immunoquantitation}

In order to estimate the variation between samples (organs from different fetuses or infants) and to analyze the variation of the measuring technique (immunoblotting), the relative IGF-II/M6P receptor content of protein extracts from two organs with high/intermediate receptor content (liver and kidney) was quantitated. Immunoblotting was performed using antiserum 66416 and ${ }^{125}$ I-protein A according to Sklar et al. (50). After drying overnight, the nitrocellulose sheets were autoradiographed using Kodak X-AR film (X-Omat AR, no. 150, 1451, Kodak, Rochester, NY) and enhancing screens (Du Pont, New England Nuclear, Boston, MA) at $-70 \mathrm{C}$. The specific receptor bands detected on $x$-ray films were cut out from the nitrocellulose filters and were counted in a $\gamma$-counter (Berthold, LB 2103, Munich, Germany). The results of three independent experiments (three independent extractions from the same organ of three human fetuses (gestational age 23, 35, and 41 weeks) and of four (kidney) and, respectively, five (liver) infants $(3,4,13,18$, and 24 months postnatal) were analyzed using Student's $t$ test. Values for fetal tissue receptor content were compared with those of postnatal tissue receptor content.

\section{Western ligand blotting}

Aliquots $(200 \mu \mathrm{g})$ of the tissue extracts were subjected to SDS-PAGE (12.5\% acrylamide-bis) under nonreducing conditions as described by Laemmli (52). Proteins were then transferred onto nitrocellulose filters by electroelution as described for the immunoblotting procedure. Ligand blotting was then carried out essentially as described by Hossenlopp et al. (53). In brief, the nitrocellulose filters were blocked in buffer containing $1 \%$ BSA, and subsequently incubated with ${ }^{125}$ I-IGF-II (Amersham, Braunschweig, Germany) diluted in $0.15 \mathrm{~mol} \mathrm{NaCl}, 10 \mathrm{mmol}$ Tris- $\mathrm{HCl}$, $1 \%$ BSA, $0.1 \%$ Tween-20, pH $7.4(20 \mathrm{~mL} /$ filter $/ \mathrm{bag})$ in the presence or absence of $2 \mu \mathrm{g} / \mathrm{mL}$ unlabeled human recombinant IGF-II (a kind gift from Dr. A. Skottner, Stockholm, Sweden) for $12 \mathrm{~h}$ at $4 \mathrm{C}$ temperature The nitrocellulose sheets were then washed extensively in a $0.15 \mathrm{~mol}$ $\mathrm{NaCl}, 10 \mathrm{mmol}$ Tris-HCl, $0.1 \%$ Tween-20, $\mathrm{pH} 7.4$ buffer, and finally in a $0.15 \mathrm{~mol} \mathrm{NaCl}, 10 \mathrm{mmol}$ Tris- $\mathrm{HCl}, \mathrm{pH} 7.4$ buffer, and dried overnight. Autoradiographs were obtained by exposing the filters to Kodak- $X$ Omat films (Eastman Kodak) using enhancer screens (DuPont, Newton, $\mathrm{CT})$ at $-70 \mathrm{C}$.

\section{Results}

\section{Specificity of immunodetection of IGF-II/M6P receptors in human tissues}

When protein extracts from human lung tissues were immunoblotted using anti-IGF-II/M6P receptor antiserum 66416 , a single band at approximately 220 kilos mol wt corresponding to the approximate molecular weight of the IGF-II/M6P receptor upon SDS-PAGE was detected on the nitrocellulose sheets and no other band was stained (Fig. 1). When control serum from normal rabbit was used instead of the antiserum no protein band was detected (data not shown). The specific receptor band was found in all lung tissues examined irrespective of the age of the donor: it was 
FIG. 1. Immunoblotting of protein extracts from human lung. Approximately $200 \mu \mathrm{g}$ protein extracts were analyzed by SDS-PAGE. Proteins were transferred by electroelution to nitrocellulose sheets, and the sheets were incubated successively with anti-IGF-II/M6P receptor antiserum and an immunoperoxidase stain as described in Subjects and Methods. The arrow points to the specific 220 $\mathrm{kDa}$ receptor band. Lung protein extracts from four fetuses and five infants were analyzed.

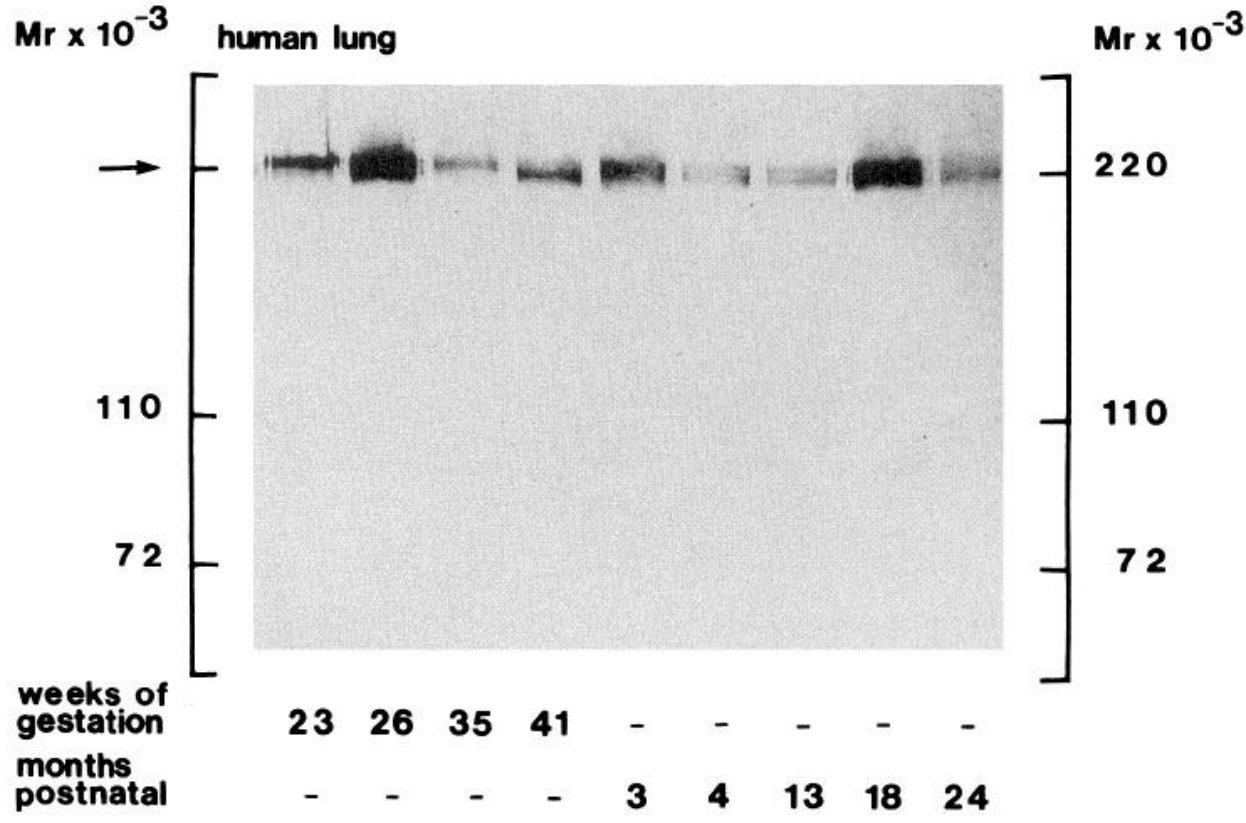

present at $23,26,35$, and 41 weeks gestational age, and 3 , $4,13,18$, and 24 months postnatal. In contrast, when protein extracts from human kidney were examined by immunoblotting, not only the 220 -kilodalton $(\mathrm{kDa})$ receptor band was stained but also protein bands at 140 and at 72,77 , and $82 \mathrm{kDa}$ were detected (Fig. 2A): the latter species were also seen when human kidney proteins were analyzed using control rabbit serum instead of the antireceptor antiserum (Fig. 2B). These proteins were also seen on blots when only the avidin horse radish peroxidase complex was added without prior exposure of the nitrocellulose sheets to any serum and/or biotinylated second antibody (data not shown). In addition, these bands had no peroxidase activity as shown by enzymatic testing using 4 -chloro- $\alpha$-naphtol as staining reagent and $\mathrm{H}_{2} \mathrm{O}_{2}$ as substrate (data not shown). These results suggest that the immunostaining procedure used in these experiments detects biotinylated proteins which are present in some (kidney, liver, muscle) but not in other (lung, brain) human organs. The anti-IGF-II/M6P receptor antiserum used throughout these experiments, however, is specific for the human IGF-II/M6P receptor as has been described originally (31). As in lung tissue, the IGF-II/M6P receptor band at an approximate molecular weight of 220 kilos was present in kidney tissues at all ages examined: it was seen in kidney extracts from 23,26 , and 41 weeks gestation fetuses and also from infants of $3,4,13,18$, and 24 month postnatal age (Fig. 2A).

\section{Immunodetection of IGF-II/M6P receptor protein-variable expression of the receptor in multiple human tissues}

When tissue extracts of heart, psoatic muscle, lung, kidney, liver, brain, testis, ovary, spleen, and thymus from 10 human fetuses and infants were analyzed for IGF-II/M6P receptor content, all organs examined contained detectable amounts of receptor protein (Fig. 3, A, B, C). Three representative immunoblots showing the analysis of tissue extracts from one fetus ( 25 weeks gestation) or infant (3- and 13-month postnatal age) respectively, are shown (Fig. 3, A, B, C). The apparent molecular weight of the receptor band varied among the organs studied: generally, the receptor in brain was of lower molecular weight than the IGF-II/M6P receptor species in the remaining eight tissues. In some organs (thymus, liver, lung, ovary, spleen) doublet bands were occasionally detected (Figs. 3 and 4). The amount of immunoreactivity ever, when the organs were grouped according to their IGFII/M6P receptor content as estimated from 10 immunoblots, heart, thymus, and kidney consistently contained the highest amount of IGF-II/M6P receptor immunoreactivity whereas brain and muscle expressed the lowest level of IGF-II/M6P receptor immunoreactivity. The receptor content in ovary, testis, liver, lung, and spleen was intermediate (Table 1).

\section{Immunoquantitation of IGF-II/M6P receptor expression during human fetal life and early infancy}

The putative developmental regulation of IGF-II/M6P receptor expression was studied by immunoblotting tissue extracts from the same organ of donors of different ages: when protein extracts of lung, liver, kidney, thymus, and heart from human fetuses $(23,26,35$, and 41 weeks gestation) and infants $(3,4,13,18$, and 24 months of age) were subjected to SDS-PAGE and immunoblotted using the specific antiIGF-II/M6P receptor antiserum 66416, the receptor protein was again found in all organs and at all ages examined: there was considerable variation of the amount of receptor protein as measured by immunoblotting between ages. However, there was no clear and consistent pattern of variation which would have indicated a developmental regulation of receptor expression in the human between 23 weeks of gestation and 24 months postnatal (Fig. 4). In addition, no sex difference measured in the different organs varied considerably. How- 


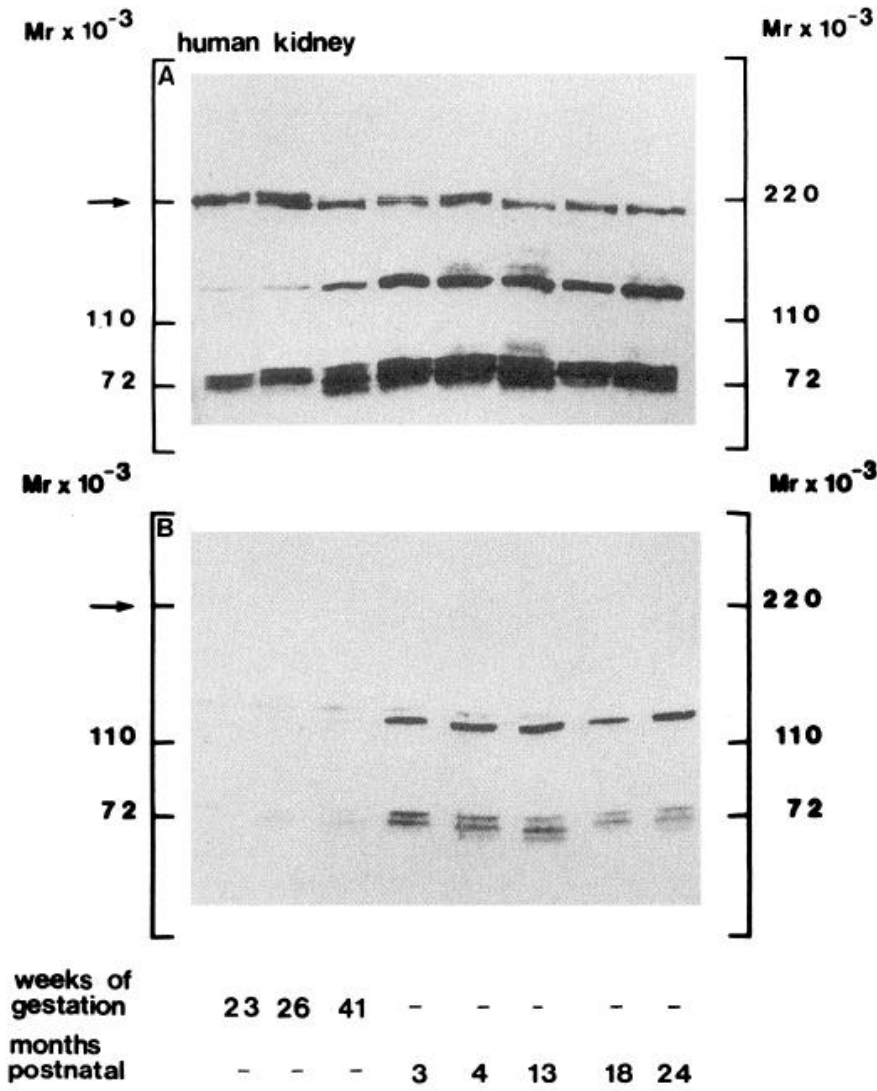

Fig. 2. Immunoblots of protein extracts from human kidney. Immunoblotting was performed as in Fig. 1. A, Anti-IGF-II/M6P receptor antiserum and an immunoperoxidase stain were applied; B, control rabbit serum and the immunoperoxidase stain were used. The arrow points to the IGF-II/M6P receptor band. Kidney protein extracts from three fetuses and five infants were analyzed. The nonspecific protein bands presumably represent biotinylated enzymes which are expressed in kidney.

of receptor expression was apparent (data not shown). To quantitate the relative amount of IGF-II/M6P receptor protein in human kidney and liver at different age points further, immunoblotting was performed using ${ }^{125}$ I-protein $\mathrm{A}$ and autoradiography for visualization of receptor species. Specific receptor bands were then cut out from the nitrocellulose sheets and radioactivity counted in a $\gamma$-counter. Again, there was considerable variation in receptor content of the same sample between experiments. More importantly, receptor content of different samples also varied greatly. In kidney, receptor content was apparently higher in samples that were obtained from fetuses than in postnatal samples. However, when statistical analysis of relative receptor content at different ages was performed, comparing three prenatal samples with four postnatal samples, no statistically significant difference was found (Table 2). In addition, no significant difference of IGF-II/M6P receptor content between three fetal and five postnatal liver samples was detected (Table 2).

Detection of tissue-specific expression of IGFBPs in multiple human tissues by Western ligand blotting with ${ }^{125}$ IGF-II

To compare the variable expression of the IGF-II/M6P receptor protein in different tissues with the presence of
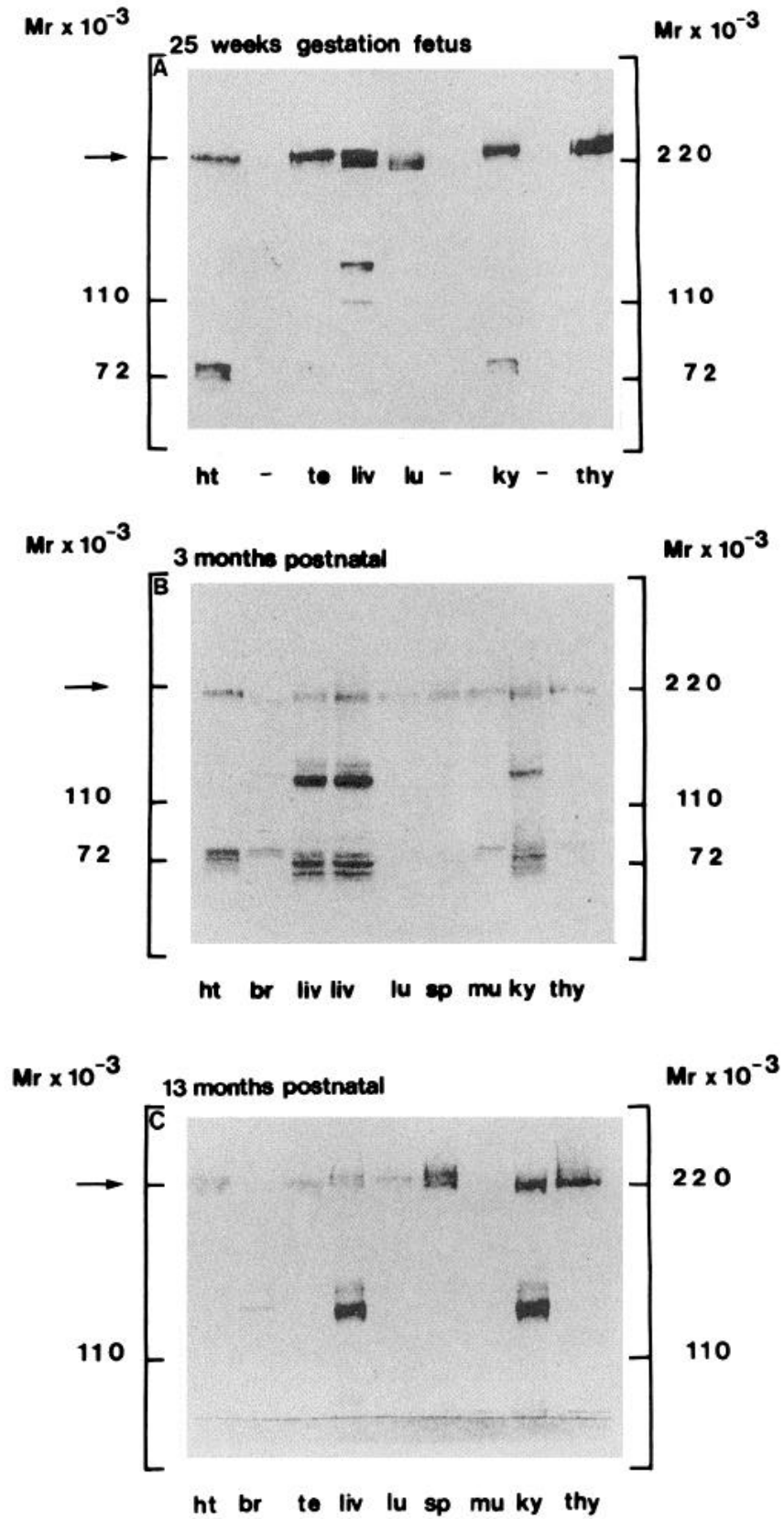

FIG. 3. Immunoblots from tissue extracts (same age, different tissues). Immunoblotting was performed as described in Fig. 1 . A, 25 weeks gestation; B, 3 months postnatal; C, 13 months postnatal.

multiple IGFBP species in the same organs, protein extracts from five different human tissues (psoatic muscle, brain, liver, lung, and kidney) were analyzed by SDS-PAGE and ligand blotting using ${ }^{125} \mathrm{I}$-IGF-II. Five distinct radiolabeled protein species with an approximate molecular weight of 43 , $38,34,30$, and 20 kilos, respectively, were detected (Fig. 5). The intensity of the radiolabeled bands varied among the tissues studied: in brain, the $34-\mathrm{kDa}$ band was predominant, while in psoatic muscle, the $30-\mathrm{kDa}$ species was the major band as seen in seven ligand blotting experiments using tissue samples from eight fetuses and infants. The apparent 


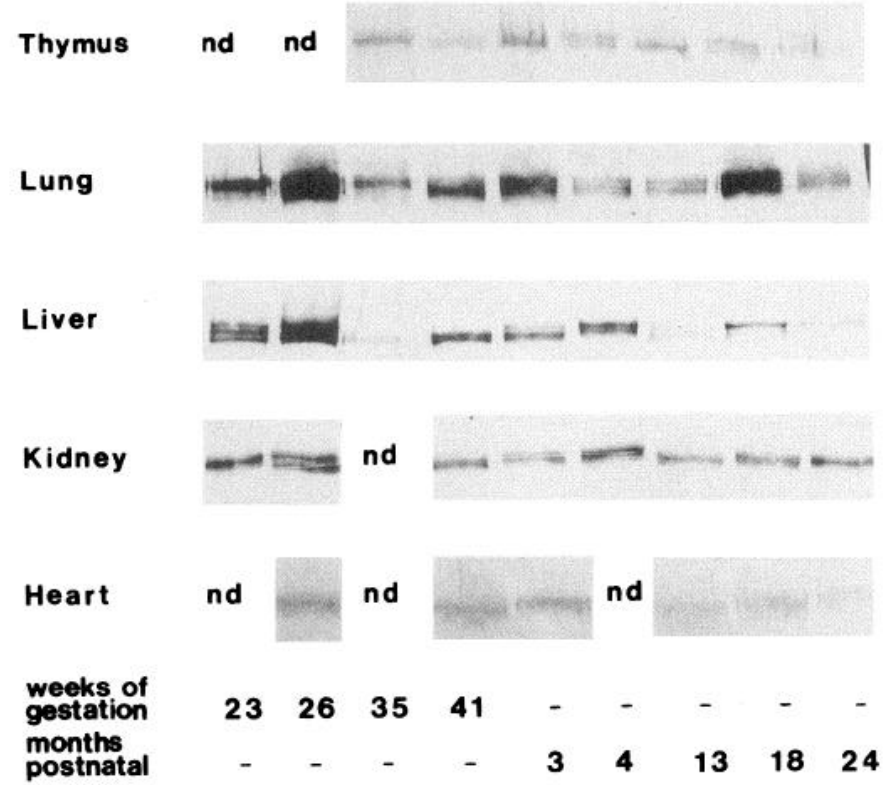

FIG. 4. Immunoblots from tissue extracts (different age, same tissue). Immunoblotting was performed as described in Subjects and Methods. Protein extracts $(200 \mu \mathrm{g})$ were applied to each lane. The $220-\mathrm{kDa}$ receptor bands from each organ are shown in a representative manner for four fetuses and five infants.

TABLE 1. IGF-II/M6P receptor content of human tissues (10 subjects, 23 weeks gestation to 24 months postnatal)

\begin{tabular}{|c|c|c|c|}
\hline & Low & Intermediate & High \\
\hline \multicolumn{4}{|c|}{$\begin{array}{l}\text { Organs with low receptor } \\
\text { content }\end{array}$} \\
\hline Brain & $\mathrm{n}=5$ & $\mathrm{n}=3$ & 0 \\
\hline Psoatic muscle & $\mathrm{n}=6$ & $\mathrm{n}=1$ & 0 \\
\hline \multicolumn{4}{|c|}{$\begin{array}{l}\text { Organs with intermediate re- } \\
\text { ceptor content }\end{array}$} \\
\hline Ovary/testis & 0 & $\mathrm{n}=8$ & 0 \\
\hline Liver & $\mathrm{n}=1$ & $\mathrm{n}=6$ & $\mathrm{n}=3$ \\
\hline Lung & $\mathbf{n}=3$ & $\mathrm{n}=5$ & 0 \\
\hline Spleen & $\mathrm{n}=1$ & $\mathrm{n}=5$ & $\mathrm{n}=2$ \\
\hline \multicolumn{4}{|c|}{$\begin{array}{l}\text { Organs with high receptor } \\
\text { content }\end{array}$} \\
\hline Heart & $\mathrm{n}=1$ & $\mathrm{n}=3$ & $\mathrm{n}=4$ \\
\hline Kidney & $\mathrm{n}=1$ & $\mathrm{n}=2$ & $\mathrm{n}=7$ \\
\hline Thymus & $\mathrm{n}=1$ & $\mathrm{n}=1$ & $\mathrm{n}=8$ \\
\hline
\end{tabular}

molecular weight of the IGFBP species found in human tissues by ligand blotting experiments corresponds well with the molecular weight of IGFBP species commonly detected in human plasma and serum. The tissue distribution of the IGFBPs cannot be explained by differential degradation in the various organs nor by contamination of the tissues by blood. A more detailed analysis of the expression of IGFBP species in human tissues has been carried out (Funk, B., U. Kessler, W. Kiess, manuscript submitted).

\section{Discussion}

The IGF-II/M6P-receptor is present in many tissues in rats, mice, and sheep $(24,47,50,54)$. The IGF-II/M6P receptor
TABLE 2. Immunoreactivity of IGF-II/M6P receptor in human kidney and liver as measured by immunoblotting and ${ }^{125}$ I-protein $\mathrm{A}$ quantitation

\begin{tabular}{|c|c|c|c|c|c|c|c|c|}
\hline & \multicolumn{3}{|c|}{$\begin{array}{l}\text { Gestational age } \\
\text { (weeks) }\end{array}$} & \multicolumn{4}{|c|}{ Postnatal age (months) } & \\
\hline & 23 & 35 & 41 & 3 & 4 & 18 & 24 & \\
\hline \multicolumn{9}{|l|}{ Kidney } \\
\hline & 415 & 505 & 472 & 546 & 253 & 163 & 95 & \\
\hline & 317 & 202 & 524 & 415 & 47 & 112 & 87 & \\
\hline & \multicolumn{3}{|c|}{$463 \pm 108^{a}$} & \multicolumn{5}{|c|}{$267 \pm 75$} \\
\hline & \multicolumn{8}{|c|}{ Mean \pm SEM } \\
\hline & \multicolumn{3}{|c|}{$\begin{array}{l}\text { Gestational age } \\
\text { (weeks) }\end{array}$} & \multicolumn{5}{|c|}{ Postnatal age (months) } \\
\hline & 26 & 35 & 41 & 3 & 4 & 13 & 18 & 24 \\
\hline \multicolumn{9}{|l|}{ Liver } \\
\hline & 93 & 266 & 476 & 455 & 374 & 76 & 364 & 37 \\
\hline & 74 & 283 & 546 & 535 & 369 & 18 & 382 & 11 \\
\hline & \multicolumn{3}{|c|}{$278 \pm 117^{a}$} & \multirow{2}{*}{\multicolumn{5}{|c|}{$262 \pm 87$}} \\
\hline & Mear & SEN & & & & & & \\
\hline
\end{tabular}

Values are means \pm SEM of triplicate measurements of counts per $\min \left({ }^{125} \mathrm{I}\right.$-protein A per $220 \mathrm{kDa}$ receptor lane).

${ }^{a}$ Receptor content of prenatal tissues does not differ significantly from receptor content of postnatal tissues.

has also been found on many cells including cell lines from human origin $(24,37)$ and in human brain, liver, and placenta $(1,2,54)$. In this study, we have measured the receptor in solubilized whole tissue extracts from human fetuses and infants ranging in age from 23 weeks gestation to $2 \mathrm{yr}$ postnatal. IGF-II/M6P receptor immunoreactivity was present in all tissues examined (brain, kidney, liver, lung, heart, testis, ovary, thymus, and spleen). As in the rat (50), brain contained the lowest concentration of IGF-II/M6P receptor protein, and heart and kidney consistently contained large amounts of receptor immunoreactivity. In addition, thymus also contained higher amounts of the receptor. Muscle, which contained high amounts of receptor protein in the rat, had only low receptor content in the human. The receptor content in ovary, testis, lung, and spleen was intermediate. As reported for the rat $(50,55)$, the human IGF-II/M6P receptor varied in size. Consistent with the results in the rat, the receptor in brain was smaller in size than that in other tissues. Presumably, this variation in receptor size reflects differential glycosylation of the receptor in the different tissues as has been suggested in the literature (55). Such variation in size also occurs during receptor synthesis in cells in culture (56, 57). Immunoreactive receptor species of lower molecular weight could thus reflect receptor precursors and indicate tissues of high receptor turnover or receptor synthesis. Alternatively, lower molecular weight receptor species could represent degradation products in proteolytic tissues $(37,48)$.

As with the IGF-II/M6P receptor protein there was also differential expression of IGFBP species in different organs: brain predominantly contained a $34-\mathrm{kDa}$ IGFBP consistent with reports in the literature of the expression of such a specific $34-\mathrm{kDa}$ IGFBP in cerebrospinal fluid (52). The differential expression of IGF-II/M6P receptors and IGFBP species in different human tissues points to specific biological 
FIG. 5. Analysis of IGFBPs in protein extracts from human tissues. Proteins were extracted and analyzed by SDSPAGE and ligand-blotting using ${ }^{125} \mathrm{I}$ IGF-II as described in Subjects and Methods. For comparison, $2 \mu \mathrm{L}$ of human serum were also analyzed on each blot. The double arrow head points to the 43$\mathrm{kDa}$ region, presumably representing the IGFBP-3 species, whereas the open arrow indicates the position of the $30-\mathrm{kDa}$ IGFBP predominantly expressed in muscle. The $34-\mathrm{kDa}$ IGFBP in brain is indicated by a filled arrow head.

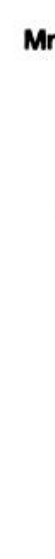

23 weeks gestation

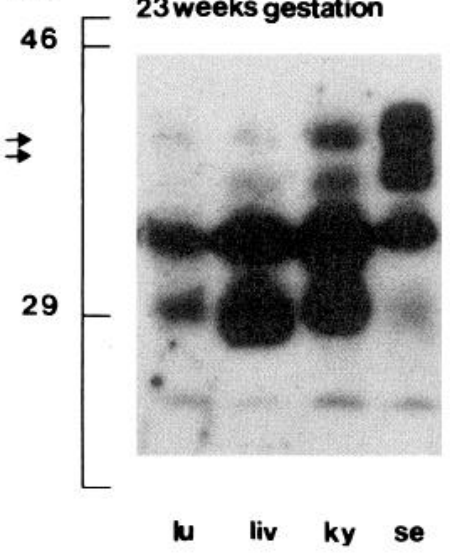

24 months postnatal

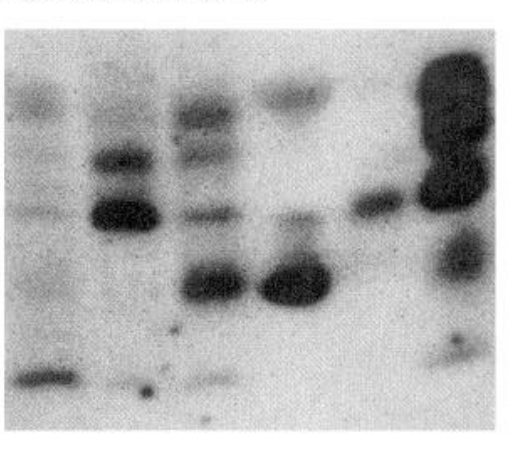

lu liv ky mu br se
$\operatorname{Mr} \times 10^{-3}$

46

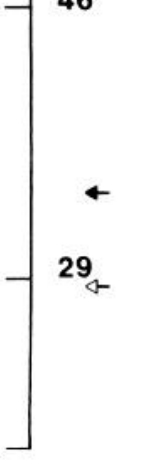

roles of the IGF binding moieties in the respective tissues and allows for modulation of IGF mediated biological effects in these organs.

In the rat, a dramatic (up to 100 -fold) difference in the amount of IGF-II/M6P receptor between fetal and postnatal serum (46) and tissues (50) has been reported. In sheep and monkey serum, developmental regulation of IGF-II/M6P receptor expression has also been suggested $(47,51)$. In the human, we have found only a minimal difference of receptor content between prenatal and postnatal kidney and no such difference in liver tissues (between 23 weeks gestation and 24 months postnatal age). It is possible that the failure to detect a significant developmental regulation of receptor expression in the human was due to 1) autolytic processes which might affect different tissues at different ages in a differential manner. However, no signs of degradation (protein smear, etc.) appeared on any of the immunoblots, and other nonreceptor related proteins (i.e. biotinylated enzymes) expressed a clear developmental pattern (Fig. 2). 2) Alternatively, a more pronounced developmental regulation of IGFII/M6P receptor expression might occur much earlier (before 23 weeks of gestation) in human life than in embryologically comparable stages of development in the rat. It is interesting to note that whereas in the rat not only the IGF-II/M6P receptor but also the ligand, i.e. IGF-II itself, are developmentally regulated, in the human both the amount of IGF-II (1-3) and of the IGF-II/M6P receptor (this study) are barely or only to a small extent regulated during fetal and early postnatal development. 3) Failure to detect a significant difference of receptor content between fetal and postnatal tissues might also be due to the large variation caused by the detection technique (immunoblots) (Table 2). However, when the receptor content of different organs was compared, a clear grouping of tissues with organs of high, intermediate, and low receptor content was evident. If a developmental pattern (fetal vs. postnatal) was as pronounced in the human as in other species (rat, sheep) (100-fold difference!), the relatively large variability of the technique and potential intersample variations would still not mask such a large difference.

Since the IGF-II/M6P receptor is present in all tissues examined and at all ages tested we hypothesize that this receptor type is involved in general functions of development and metabolism. The variable amounts of receptor protein present in different organs at different times of development make the IGF-II/M6P receptor a likely candidate of regulatory processes that might be involved in organ development, growth, and tissue remodeling. The receptor would add to the variability of IGF binding capacity in different tissues caused by the differential expression of IGFBP classes in the various organs. In addition, the IGF-II/M6P receptor binds two classes of ligands, namely, a growth factor, IGF-II, and a number of lysosomal enzymes bearing the mannose-6phosphate recognition marker $(29,30)$. This latter function might also be of biological importance during development and in different tissues. The fact that the IGF-II/M6P receptor maintains - as demonstrated by receptor-ligand blotting (data not shown) - its function of binding IGF-II in all tissues examined, further points to an interconnected network of tissue degradation and growth processes that meet at the cellular level, i.e. at a common receptor site.

\section{Acknowledgments}

We are grateful to Drs. S. Peter Nissley and M. M. Sklar, Bethesda, MD, and K. von Figura, Göttingen, Germany, for many helpful suggestions. We wish to express our special gratitude to Dr. W. Sly, St. Louis, MO, for his generous gift of anti-IGF-II/M6P receptor antiserum and to Dr. H. P. Schwarz, Munich, Germany, for his continuous support.

\section{References}

1. Humbel R. 1990 Insulin-like growth factors I and II. Eur J Biochem. 190:445-62.

2. Rechler MM, Nissley SP. 1990 Insulin-like growth factors. In: Sporn MB, Roberts AB, eds. Peptide growth factors and their receptors. I. Handbook of pharmacology. Heidelberg, New York: Springer Publisher; 263-367.

3. Daughaday WH, Rotwein P. 1989 Insulin-like growth factors/ somatomedins. Peptide, mRNA and gene structures, serum, and tissue concentrations. Endocr Rev. 10:68-90.

4. Rinderknecht E, Humbel RE. 1978 Primary structure of human IGF-II. FEBS Lett. 89:283-6.

5. Marquard H, Todaro GJ, Henderson LE, Oroszlan S. 1981 Purification and primary structure of a polypeptide with multiplication- 
stimulating activity from rat liver cell cultures. J Biol Chem. 256:6859-65

6. Hasselbacher G, Irminger JC, Zapf J, Ziegler WH, Humbel RE. 1987 IGF-II in human adrenal pheochromocytomoas and Wilms tumors: expression at the mRNA and protein level. Proc Natl Acad Sci USA. 84:1104-6.

7. Ron D, Powers AC, Pandian MR, Godine JE, Axelrod L. 1989 Increased IGF-II production and consequent suppression of GH secretion: a dual mechanism for tumor induced hypoglycemia. J Clin Endocrinol Metab. 68:701-6.

8. Daughaday WH, Kapadia M. 1989 Significance of abnormal serum binding of IGF-II in the development of hypoglycemia in patients with non-islet-cell tumors. Proc Natl Acad Sci USA. 86:6778-82.

9. Daughaday WH. 1990 Editorial: the possible autocrine/paracrine and endocrine roles of IGFs of human tumors. Endocrinology. 127:1-4.

10. Adams SO, Nissley SP, Greenstein LA, Yang YW-H, Rechler MM. 1983 Synthesis of MSA (rat IGF-II) by rat embryo fibroblasts. Endocrinology 112:979-87.

11. Romanus JA, Yang YW, Adams SO, et al. 1988 Synthesis of IGFII in fetal rat tissues: translation of IGF-II RNA and processing of pre-pro-IGF-II. Endocrinology. 122:709-16.

12. Lund PK, Moats-Staats BM, Hynes MA, et al. 1986 IGF-I and -II mRNAs in rat fetal and adult tissues. J Biol Chem. 261:14539.

13. Moses AC, Nissley SP, Cohen KL, Rechler MM. 1976 Specific binding of a somatomedin-like polypeptide in rat serum depends on GH. Nature. 263:137-40.

14. Beck F, Samani NJ, Penschow JD, Thorly B, Tregear GW, Coghlan JP. 1987 Histochemical localization of IGF-I and -II mRNA in the developing rat embryo. Development. 101:175-84.

15. Daughaday WH, Trivedi B, Kapadia M. 1981 Measurement of IGF-II by a specific RRA in serum of normal individuals, patients with abnormal GH secretion and patients with tumor associated hypoglycemia. J Clin Endocrinul Metab. 53:289-94

16. Zapf Walter H, Froesch ER. 1981 Radioimmunological determination of IGF-I and -II in normal subjects and in patients with growth disorders and extrapancreatic tumor hypoglycemia. J Clin Invest. 68:1321-30

17. Furlanetto RW, Underwood LE, Van Wyk JJ, D'Ercole AJ. 1977 Estimation of SM-C levels in normals and patients with pituitary disease by RIA. J Clin Invest. 60:638-57.

18. Blum WF, Ranke MB, Bierich JR. 1988 A specific radioimmunoassay for IGF-II: the interference of IGF binding proteins can be blocked by excess IGF-I. Acta Endocrinol (Copenh). 118:374-80.

19. Kiess W, Thomas CL, Greenstein L, et al. 1989 IGF-II inhibits both the cellular uptake of beta-galactosidase and the binding of betagalactosidase to purified IGF-II/M6P receptor. J Biol Chem. $264: 4710-4$

20. Kiess W, Thomas CL, Sklar MM, Nissley SP. 1990 Beta-galactosidase decreases the binding affinity of the IGF-II/M6P receptor for IGF-II. Eur J Biochem. 190:71-7.

21. Mathieu M, Rochefort H, Barenton B, Prebois C, Vignon F. 1990 Interactions of cathepsin D and IGF-II on the IGF-II/M6P receptor in human breast cancer cells and possible consequences on mitogenic activity of IGF-II. Mol Endocrinol. 4:1327-35

22. Nolan CM, Kyle JW, Watanabe H, Sly WS. 1990 Binding of IGFII by human cation-independent M6P/IGF-II receptor expressed in receptor-deficient mouse L cells. Cell Differ. 1:197-213.

23. Ullrich A, Gray A, Tam AW, et al. 1986 IGF-I receptor primary structure: comparison with insulin receptor suggests structural determinants that define functional specificity. EMBO J. 5:2503-12

24. Rechler MM, Nissley SP. 1985 The nature and regulation of the receptors for IGFs. Annu Rev Physiol. 47:425-42.

25. Kiess W, Haskell JF, Lee L, et al. 1987 An antibody that blocks IGF binding to the type II IGF receptor is neither an agonist nor an inhibitor of IGF-stimulated biologic responses in L6 myoblasts. J Biol Chem. 262:12745-51.

26. Mottola C, Czech MP. 1984 The type II insulin-like growth factor receptor does not mediate increased DNA synthesis in H-35 hepatoma cells. J Biol Chem. 259:12705-13.

27. Furlanetto RW, DiCarlo JN, Wisehart C. 1987 The IGF-II receptor does not mediate DNA synthesis in human fibroblasts. J Clin
Endocrinol Metab. 64:1142-9.

28. Corvera S, Whitehead RE, Mottola C, Czech MP. 1986 The IGFII receptor is phosphorylated by a tyrosine kinase in adipocyte plasma membranes. J Biol Chem. 261:7675-9.

29. Morgan DO, Erdman JC, Standring DN, et al. 1987 IGF-II receptor as a multifunctional binding protein. Nature. 329:301-7.

30. MacDonald RG, Pfeffer SR, Coussens L, et al. 1988 A single receptor binds both IGF-II and mannose-6-phosphate. Science. 239:1134-7.

31. Oshima A, Nolan CM, Kyle JW, Gruff H, Sly WS. 1988 The human cation-independent $\mathrm{M} 6 \mathrm{P}$ receptor. Cloning and sequence of the full-length cDNA and expression of functional receptors in cos cells. J Biol Chem. 263:2553-62.

32. Tong PY, Tollefsen E, Kornfeld S. 1988 The cation-independent M6P receptor binds IGF-II. J Biol Chem. 263:2585-8.

33. Braulke T, Causin C, Waheed A, et al. 1988 M6P/IGF-II receptor: distinct binding sites for mannose-6-phosphate and IGF-II. Biochem Biophys Res Commun. 150:1287-93.

34. Polychronakos C, Guyda HJ, Posner BI. 1988 Mannose-6-phosphate increases the affinity of its cation-independent receptor for IGF-II by displacing inhibitory endogenous ligands. Biochem Biophys Res Commun. 157:632.

35. Roth RA, Stover C, Hari J, Morgan DO, Smith MC, Sara V, Fried VA. 1987 Interactions of the receptor for IGF-II with M6P and antibodies to the M6P receptor. Biochem Biophys Res Commun. 149:600-6

36. Kiess W, Blickenstaff GD, Sklar M, Thomas C, Nissley SP, Sahagian GG. 1988 Biochemical evidence that the type II IGF receptor is identical to the cation-independent M6P receptor. J Biol Chem. 263:9339-44.

37. von Figura K, Hasilik A. 1986 Lyosomal enzymes and their receptors. Annu Rev Biochem. 55:167-93.

38. Pfeffer SR. 1988 M6P receptors and their role in targeting proteins to lysosomes. J Membr Biol. 103:7-16.

39. Dahms NM, Lobel P, Kornfeld S. 1989 M6P receptors and lysosomal enzyme targeting. J Biol Chem. 264:12115-8.

40. Tally M, Li CH, Hall K. 1987 IGF-Il stimulated growth mediated by the somatomedin type II receptor. Biochem Biophys Res Commun. 148:811-6.

41. Rogers SA, Hammerman MR. 1988 IGF-II stimulates production of inositol trisphosphate in proximal tubular basolateral membranes from dog kidney. Proc Natl Acad Sci USA. 85:4037-41.

42. Bhaumick B, Bala RM. 1988 Parallel effects of IGF-II and insulin on glucose metabolism of developing mouse embryonic limb buds in culture. Biochem Biophys Res Commun. 152:359-62.

43. Okamoto T, Katada T, Murayama Y, Ui M, Ogata E, Nishimoto I. 1990 A simple structure encodes $G$ protein-activating function of the IGF-II/mannose-6-phosphate receptor. Cell. 62:709.

44. Hari J, Pierce SB, Morgan DO, Sara V, Smith MC, Roth RA. 1987 The receptor for IGF-II mediates an insulin-like response. EMBO J. 6:3367-71.

45. Vetter U, Zapf J, Heit W, et al. 1986 Human fetal and adult chondrocytes. Effect of IGF-I and -II, insulin and growth hormone on clonal growth. J Clin Invest. 77:1903-8.

46. Kiess W, Greenstein LA, White RM, Lee L, Rechler MM, Nissley SP. 1987 Type II IGF receptor is present in rat serum. Proc Natl Acad Sci USA. 84:7720-4

47. Gelato MC, Kiess W, Lee L, Malozowski S, Rechler MM, Nissley SP. 1988 The IGF-II/M6P receptor is present in monkey serum. I Clin Endocrinol Metab. 67:669-75.

48. Causin C, Waheed A, Braulke T, et al. 1988 M6P/IGF-II binding proteins in human serum and urine. Biochem J. 252:795-9.

49. Claimont KB, Czech MP. 1991 Extracellular release as the major degradative pathway of the IGF-II/M6P receptor. J Biol Chem. 266:12131-4.

50. Sklar M, Kiess W, Thomas CL, Nissley SP. 1989 Developmental expression of the tissue insulin-like growth factor-II/mannose-6phosphate receptor in the rat. J Biol Chem. 264:16733-8.

51. Hey AW, Browne CA, Thorburn GD. 1987 Fetal sheep serum contains a high molecular weight IGF binding protein that is acid stable and specific for IGF-II. Endocrinology. 121:1975-84.

52. Laemmli UK. 1970 Cleavage of structural proteins during the 
assembly of the head of bacteriophage T4. Nature. 227:680.

53. Hossenlopp P, Seurin D, Degovia-Quinson B, Hardouin S, Binoux M. 1986 Analysis of serum insulin like growth factor binding proteins using Western blotting: use of the method for titration of the binding proteins and competitive binding studies. Anal Biochem. 154:138-43.

54. Nissley SP, Kiess W, Sklar MM. 1991 The IGF-II/mannose-6phosphate receptor. In: LeRoith D, ed. IGFs: molecular and cellular aspects. Boca Raton, FL: CRC Press.
55. Taylor JE, Scott CD, Baxter RC. 1987 Comparison of receptors for insulin-like growth factor II from various rat tissues. J. Endocrinol. 115:35.

56. MacDonald RG, Czech MP. 1985 Biosynthesis and processing of the type II insulin-like growth factor receptor in H-35 hepatoma cells. J Biol Chem. 260:11357-65.

57. Kiess W, Greenstein LA, Lee L, Thomas C, Nissley SP. 1991 Biosynthesis of the IGF-II/M6P receptor in rat C6 glial cells: the role of N-linked glycosylation in binding of IGF-II to the receptor. Mol Endocrinol. 5:281-91. 